\title{
Necati’nin Redifi Yer Ve Şahıs İsmi Olan Gazellerinde Tasvir Unsurları
}

\author{
Bayram ÇELİK \\ Kırıkkale Üniversitesi, Eski Türk Edebiyatı
}

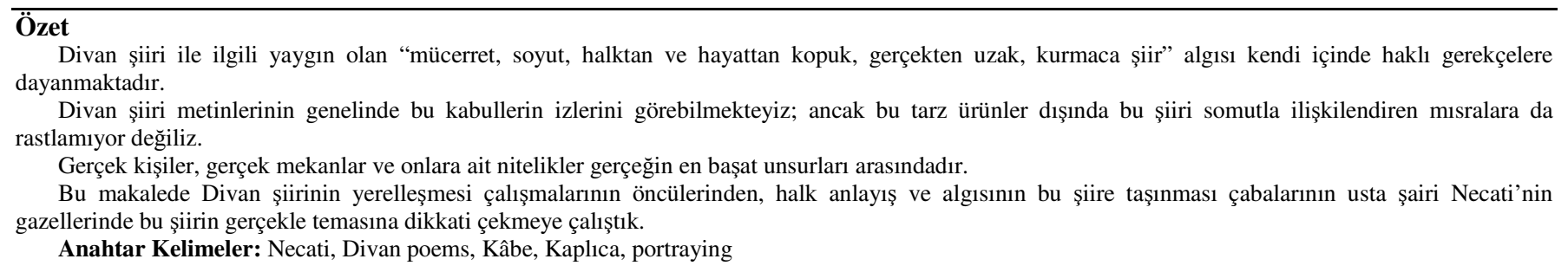

\section{Locatıons, Names And Description Elements In The Gazel Of Necati}

\begin{abstract}
The common poetry perception for Divan poetry like "absolute, abstract, broken off from people and life and far away from reality, fictional" is based on valid grounds within itself.

Although we can observe similar marks of this admittance in the text of Divan poetry, we can stil see the wordings which link the poems with the concrete.

Real persons, real places and their characteristics are among of principal elements of this reality.

In this article, we have tried to draw attention to relation between reality and the lyrics of Necati who is one of the pioneers that worked on localization of Divan poetry and is the master poet that worked the understanding of perception of people to wards to this poetry style.

Key Words: Necati, Divan poems, Kâbe, Kaplıca, portraying
\end{abstract}

\section{Giriș}

Divan şiirinde tasvir önemli bir unsurdur. Tasvir etme bir ustalık bir kabiliyet göstergesi sayılabilir. Bir gözlem kabiliyeti isteyen tasvirlere de divan şairi sıkça başvurmuştur. Başarılı tasvir şairi güçlü kılar. Şiiri "kelimelerle çizilen resim" olarak tanımlarsak, tasvirin şiiri ve şairi daha etkili bir şekilde öne çıkaracağını öngörebiliriz. Tasvirin etkili kullanımı şiiri ve şairi elbette daha kudretli hale getirir. Çarpıcı tabloların süslediği şiir, belleklerde izler bırakır.

Divan şiirinin hayattan ve toplumdan kopuk bir şiir olduğu düşüncesinden yola çıkarak bu şiirde dile getirilen mekan ve doğa tasvirlerinin soyut olduğunu iddia eden fikirlerin yanlışlığını artık uzun boylu anlatmaya gerek yoktur. Bu toplumun birer ferdi olan Divan şairleri anlattıkları yer açısından da toplumu yansitiyorlardi. Bunun aksi izah edilemez. Zira bu şairler somut bir ortamda yaşadıkları için ister istemez çevreden ve o çevreyi oluşturan kişilerden izleri şiire taşıyacaklardı.

Divan şiirinin kendine has sembollerle yüklü hayâl dünyası vardır; ancak bu reel hayatın şiire girmesine engel değildir. Zaten kıyafetnamelerin, seyahatnamelerin, şehrengizlerin olduğu bir edebiyata "mekân ve gerçeklerden kopuktur" demek çok büyük haksızlık olur.

Meseleyi daha iyi açıklamak için birçok örneklendirmeye gidilebilir. Ancak, hayallerin, sanatların, yoğunluğun ve soyutluğun en fazla göze battığı gazellerde bile kişi ve yer tasvirlerine rastlanıyorsa bu fikir verme açısından iyi bir örnek olur kanaatindeyim. Hayatın içinde olan bir edebiyatın tasvir bağlamında hayata bigane kalması düşünülemez. Buradan yola çıkarak Divan edebiyatının önemli şairi olan Necati'nin yer ve kişi redifli gazellerindeki tasvir unsurlarını incelemeye çalışacağız.

Bu çalışmada Necati'yi seçmemizin en önemli sebebi, bu şairimizin, Divan edebiyatında gerçek hayata, halkın algı ve yaşayışına, halka ait deyim ve deyişlere kısaca hayata ciddi anlamda temas eden ilk şairlerimizden olmasıdır.

Necâti döneminde "melikü'ş-şu'ara" olarak bilinir. Dönemin önde gelen şairlerinin başı, yani şairlerin sultanıdır. Türkçeye vukufiyeti, onu kullanım şekli ve külfetsiz anlatımı ile Divan şiirinde kendine has bir çizgisi vardır. Kendinden sonraki şairleri (Baki, Fuzulî, Nedim...) etkilemiştir.

Necati Bey’in Türkçesi, “şehirli Türkçesi'dir. Divanında yer alan gazellerin çoğu Türkçe kelimelerle kafiyelenmiştir. ${ }^{1}$ Tezkirelerde de büyüklüğü devamlı öne çıkarılan, vurgulanan bir şairdir.

Latifî, onun şiirinin Osmanlı şairlerinin yüz suyu olduğunu, Aşık Çelebi de İran şairlerinin kendileri ayarında şair bulunmadığı yolunda bizi kınayıp, laf atarak yaralayıcı

\footnotetext{
${ }^{1}$ Solmaz, Yrd. Doç. Dr. Süleyman, Necati Bey, Akçağ Yay. S.19, Ankara 2012
} 
sözler söylemelerinden Necati Bey'in kurtardığını ifade ederek, onu bizde ilk orijinal şair olarak göstermiştir. ${ }^{2}$

Necati'nin şiirlerinde dilimize, edebî zevkimize yönelik daha birçok keşfedilmeyi bekleyen unsur olduğunu düşünmekteyiz.

\section{A) NECATI'NIN REDIFİ YER ÍSMI OLAN GAZELLERINDE TASVIR UNSURLARI 1) KABE}

\author{
GAZEL $^{3}$ \\ Benzetirken yâr eşiğin ehl-i diller Ka'beye \\ Başlamamış idi İbrahim-i Âzer Ka'beye
}

Eşiğine ko doyunca süreyim yüzüm gözüm Çok sürülür çün bilirsen sim ü zer Ka'beye

Taş eşiğin secde-gâh edinmez isem dostum Taş atanlardan olayım iy birader Ka'beye

Kuyuna meyl eylerem gamdan halâs olmağ için Bellidir azâd olur varınca çaker Ka'beye

Sen yanından sürdüğünce ben eşiğin gözlerim Kim gider âdet durur ma'zul olanlar Ka'beye

Ey cemâlinden mu'anber kâkülün terci-i bend Kim anı da'va ile şairler asar Ka'beye

Halkı kapın ettiğin mihnet odundan halâs Kim görürse der ki yârâb nice benzer Ka'beye

Y1kmak ister dostum düşman Necati gönlünü Koma kim kasd eyledi göz göre kâfer Ka'beye

Kabe ve onun betimleme unsurlarına geçmeden önce Kabe'nin genel özellikleri ile ilgili bazı bilgileri hatırlamak gerekir.

Beytullah, Beytü'l Harem, Kabetullah adlarıyla da bilinen Kabe, Mekke'de siyah taşlarla bina edilmiştir. İbrahim peygamber tarafından bugünkü, yerine inşa edilmiş olup cahiliye devrinde tamir görmüştür. Mekke fethinden sonra Kabe putlardan temizlenmiş ve hicretin ikinci yılında müslümanların kıblesi olarak belirlenmiştir. Kabe'nin Mizab denilen saçağı, astar-1 Kâbe denen kara örtüsü, zemzem suyu, hac... Divan şiirinde geniş çağrışımlara yol açan konulardan olmuştur. Edebiyatta aşk, sevgi, güzellik, kavuşma vs. imajlar için Kabe adı çokça anılır. Sevgilinin yüzü ve mahallesi tenasüb yoluyla Kabe'ye benzetilir. Tasavvufa göre Kâbe bir semboldür. Asıl Kâbe gönüldür. İlahi aşk gönülde tecelli ettiği için gönül de bir Kâbe sayılır. Allah'ın evi olduğu için de gönül ile benzerlik kurulur. ${ }^{4}$

1. Benzetirken yâr eşiğin ehl-i diller Kâ'be'ye Başlamamış idi İbrahim-i Azer Kâ'be'ye (Gönül ehli olanlar yârin eşiğini Kâbe'ye benzetirken, Azer'in oğlu İbrahim henüz Kabe'yi yapmaya başlamamıştı.)

\footnotetext{
${ }^{2}$ Şentürk, Ahmet Atilla-Kartal, Ahmet, Eski Türk Edb.

Tarihi, Dergâh, s.134 İst. 2011

${ }^{3}$ Necati Bey Divanı, Akçağ Yay. S.353

${ }^{4}$ Pala, İskender, Ans. Divan Şiiri Sözlüğü Akçağ, s.269, Ankara
}

Bu beyitte Kabe ile ilgili bir tasvir yoktur.. Ancak Kabe'nin yapılışı ve aşıkların onu benzetme unsuru olarak kullanmaları ile ilgili bilgilere rastliyoruz.

2. Eşiğine ko doyunca süreyim yüzüm gözüm Çok sürülür çün bilirsen sim ile zer Kâ'beye (İzin ver de eşiğine doyasıya yüzümü, gözümü süreyim; çünkü biliyorsun ki Kabe'ye çok gümüş ve altın sürerler.) $\mathrm{Bu}$ beyitte şair Kabe'nin dış görünüşüne ait bilgiler ve tasvir unsurları verilmiştir. Kabe'nin muhtelif yerleri adı geçen madenlerle (altın ve gümüş) süslenmiştir. Kabe'nin içinde altın ve gümüş kandiller vardır. Kabe'nin örtüsünün yukarısından üçte ikisinden itibaren altın işlemeli, bir şerit (hizam) geçirilmiş olup hüsn-i hat ile yazılmış sûreler bulunmaktadır. Şimal-i garbi duvarının içinde, yerden $2 \mathrm{~m}$. yükseklikte yaldızlı, gümüş kaplı bir kapı vardır, Kabe'de altın yaldızlı bir oluk vardır. ${ }^{5}$ Bu veriler 1 șı ğında bu beyitte Kabe'ye ait birtakım tasvir unsurlarının varlığından söz edebiliriz.

3. Taş eşiğin secde-gâh edinmez ise dostum Taş atanlardan olayın ey birader Kâ'be'ye

(Ey dostum, Kabe'nin taş eşiğini secdegâh edinmezsem, Kabe'ye taş atanlardan oldayım)

Burada Kabe ile ilgili bir "taş atanlar" meselesi var. Olay kısaca şöyle: Hicretin 8. yılında Mekke'nin fethi sırasında Peygamber Kabe'de bir değişiklik yapmamıştır. Fakat rivayete göre sonradan Mekkelilerin henüz pek yeni olan ihtidalarının onu burada herhangi bir yenilik yapmaktan alıkoyduğunu Peygamberin bu hakiki rivayette kalan yenileștirme arzusu 683 yılında Abdullah bin El-Zübeyr tarafından gerçekleştirilmiştir. Emevi halifesinin rakibi olan Abdullah Mekke'yi muhasara etti. Mekke'yi çeviren dağların üzerine mancınıklar konularak şehir ve Kabe bir taş yağmuruna tutuldu. Beytullah delik-deşik oldu ${ }^{6}$. Bu beyitte Kabe'nin belli dönemdeki delik deşik olma realitesi ifade edilmiş. Dönemsel verilerde de olsa tasvir ifadeleri misralarda yer almıştır.

4. Kûyuna meyl eylerem gamdan halâs olmak için Bellidir âzad olur varınca çâker Kâ'beye

(Gamdan, acıdan kurtulmak için senin olduğun yere gelirim, yönelirim. Çünkü esirler Kabe'ye varınca özgür olur.)

Buradaki esir manevi anlamda kullanılmıştır. Günahkar insan nefsinin esiridir. Kabe'ye varınca özgür olur. Yani insan Kabe'ye varınca nasıl günahlarından kurtulursa, ben de senin yanına gelince gamdan kurtulurum.

Burada Kabe'nin manevi yönüne ve fonksiyonuna ait bir durum var. Ka'be'nin mahiyeti ve asıl işlevi vurgulanmıştır. Kabe insanı günahlarından arıtan bir yerdir.

5. Kûyuna gelmek ile âşık denilmesin rakib Hacı olmaz bellidir varmăg ile har Kâ'beye (Senin bulunduğun yere geldiği için rakip aşık olduğunu zannetmesin. Zira eșek Kabe'ye varmakla hacı olmaz.)

$\mathrm{Bu}$ beyitte Kabe'nin herhangi bir yönüne ait tasvir yapılmamıştır. Hac farizasının yerine getirildiği yer olduğu hatırlatılmıştır.

6. Sen yanından sürdüğünce ben eşiğin gözlerim Kim gider âdet durur ma'zul olanlar Kâ'beye (Sen beni yanından uzaklara atınca ben senin eşiğini gözlerim. Çünkü Kabe'ye ancak hac için, özgür olanlar gider. )

\footnotetext{
${ }^{5}$ İslam Ansiklopedisi, MEB Yay., 6. Cilt, s.6

${ }^{6}$ A.g.e
} 
Sevgilinin semti Kabe'ye benzetildiği için şair tekrar onun kapısına gidiyor. Şairin sevgili ile olan ilişkisinin anlatıldı ğ bu gazelde bu beyit de Kabe tasvirinden uzak ancak hac farizasını yerine getirmek için Kabe'ye gidecek olan insanların özgür olmaları gerektiğine dair bir bilgi vermektedir.

7. Ey cemalinden mu'anber kâkülün terci-i bend Kim anı da'vâ ile şairler asar Kâ'be'ye

(Terci-i Bend olan kokulu saçının güzelliğinden dolayı Ey sevgili, onu şairler Kabe'ye asarlar.)

Şair bu beyitte eski bir geleneğe telmih yapıyor . Cahiliyet Döneminde çok beğenilen yedi Arap kasidesi Kâbe'ye asılırdı. Buna Muallakatü's-seba (Yedi askı) adı verilirdi.

Eski Araplar haram aylar denilen Zilkade, Zilhicce, Recep ve Muharrem boyunca çeşitli bölgelerde panayırlar kurar ve birçok eğlencenin yanı sıra şiir yarışmaları düzenlerlerdi. Bu yarışmalarda birinci gelen şiirler keten yaprağı üzerine altın ile yazılıp daha güzeli yazılana kadar Kabe kapısına asılırdı. Bu telmih unsuru o dönemdeki Kabe'ye ait tasviri unsurdur.

Şair sevgilinin saçının Kâ'beye asılmasıyla aslında Kabe'nin örtüsüyle ilgili bir başka benzetme yapıyor. Bildiğimiz gibi Kabe'nin örtüsü siyah ve değerlidir. Sevgilinin saçı da siyah ve aşık için son derece değerlidir. Çünkü aşı̆̆ı ilk defa sevgiliye bende eden saçıdır. Kabe'nin örtüsü Osmanlı döneminde her yıl değiştirilirdi. İstanbul'da hazırlanan örtü büyük bir törenle Surre Alayı eşliğinde Kabe' ye götürülmek üzere Üsküdar'dan yola çıkarılırdı. Bu durum örtüye verilen önemin bir göstergesi ve Kabe'ye ait bir tasvirdir. Bu arada Kabe'nin sade, yalın, gösterişsiz şekli onun önemli ve mesaj içeren bir özelliği olsa gerek.

8. Halkı kapın ettiyiçün mihnet odundan halas Kim görürse der ki ya Rab nice benzer Kabe'ye

(Senin kapın halkı sıkıntı ateşinden kurtardığı için kim görürse "ya Rab bu ne kadar da Kabe'ye benzer" der)

Bu beyitte yine Kabe'nin fonksiyonuna ait bir bağlantı kurma var. Kabe'ye giden insanlar günahlarından ve onların verdiği sıkıntılardan arınırlar. Şair aynı şeyi sevgilinin bulunduğu yerde de geçerli sayıyor.

Fuzulide aynı telmihi Leyla ile Mecnun mesnevisinde işler. Babası aklını yitirdiğini düşündüğü Kays'ı bu sıkıntıdan kurtarmak için Kabe'ye götürür, Ona Allah'ın onu bu sıkıntıdan kurtarması için yalvarmasını söyler. Ancak Kays tam tersini söyleyerek, bu beladan mutlu olduğunu, daha fazla istediğini ve bu dertden ayrılmak istemediğini nazm eder. Divan şiirinin de önemli eserlerinden olan Fuzûli'nin "beni" redifli o gazeli, Kabe'ye olan teveccühün manevi yönünü öne çıkaran şiirlerden biridir.

9. Y1kmak ister dostum düşman Necati gönlünü Koma kim kasd eyledi göz göre kafir Kabe'ye

(Ey dostum, düşman Necati'nin gönlünü kırmak, yıkmak ister. Sakın izin verme. Çünkü göz göre göre kafir Kabe'ye kasd eyledi,)

Bu son beyitte tasvirden ziyade Kabe gönül ilişkisi ön plana çıkıyor. Kabe insanın gönlüdür, Kabe'nin bir sembol olduğunu daha önce belirtmiştik.

Görüldügü gibi Necati Kabe redifli bu gazelinde esas alıp bu arada etkileyiciliği artırmak için telmih unsurlarını ve betimleme öğelerini kullanmıştır. Kabe'yle ilgili bilgiler ve telmih unsurları daha ağırlıklı olarak kullanılmış. Zaten şair, Kabe'yi anlatma niyetinde değil. Asıl sevgiliyle ilgili anlatımlar esas alınıp bu arada etkileyici bir unsur olarak da
Kabe kullanılmış. Bunun yanında Kabe ile ilgili tasvirler yapılmıştır.

\section{MISIR}

\author{
GAZEL ${ }^{7}$ \\ Ela ey Yusuf-1 Kenanı Misrin \\ Azizi alemin sultanı Misrın \\ Gözümden gitmesin haddin hayali \\ Kenar-1 Nil olur seyranı Misrın \\ Benim beglenmesin hadinde zira \\ Habeş olduğu yok sultanı Misrın \\ Halas olmaz zenahdanın esiri \\ Müebbed haps imiş zindanı Mısrın \\ Tavaf-1 Kabedir kûyu Necati \\ Saçı Sâmın ruh-1 handanı Mısrın
}

Mısır çeşitli açılardan Divan şiirinde kullanılmış bir ülke ismidir. Misır ülkesi uzun yıllar Osmanlı'nın hakimiyetinde kalmıştır. Mısır denilince akla Hz. Yusuf kıssası gelir. Devlet olarak Mısır'in fethi 16.yy'da olmuştur. Necati'nin ise 1509'da öldüğü vakıadır ${ }^{8}$. Ancak Mısır eski edebiyatımızda bilinen ve şiirlerde telmih unsuru olarak kullanılan bir ülkeydi.

\section{Elâ ey Yusuf-1 Kenanı Misrın}

Azizi alemin sultanı Misrın

(Ey şimdi bilmiş ol ki, Mısır'ın Kenanlı Yusuf'u; alemin azizi, Misır'in sultanıdır.)

$\mathrm{Bu}$ beyitte daha önce de belirttiğimiz gibi Misır yine Hz. Yusufla birlikte anıliyor. Misir'dan ziyade Hz. Yusuf övülüyor. Fakat Hz, Yusuf'un Misır'a sultan olması satılan bir köle iken değerli birisi olması hatırlatılıyor.

2. Gözümden gitmesin haddin hayali

Kenar-1 Nil olur seyranı Misrın

(Boyunun hayali gözümden gitmesin. Nitekim Misır'in gezilecek görülecek yeri Nil'in kenarıdır.)

Mısır' ın hayat kaynağı olarak bilinen nehir olan Nil, ülkeyi baştan başa geçer. Divan şiirinin coğrafyası içinde önemli bir yer tutar. Mısır'a sağladığı bereket ve feyiz ile ele alınır. İçinde timsahlar da bulunan Nil, mavi rengi ile de şiirlerde konu edilir ${ }^{9}$.

Şair burada Nil ile sevgili arasında bir bağlantı kuruyor. Mısır'ın gezilecek yeri Nildir. Nil esasen Mısır'ın her şeyidir. Nilsiz Misır çok geri bir ülke olurdu. Gelişmezdi. Nil olmadan Misır güzel ve müreffeh olmaz. Burada Nil, Misır için neyse, şair için de sevgilinin boynunun aynı değerde olduğunu söylüyor. Burada sosyal bir gerçekten bahsediliyor. Şair Nil'in uzun ve düzgün boyunu sevgilinin boyu ile özdeşleştiriyor. Sevgilinin boyu, önemi gibi yönleri ile Nil'e benziyor. Burada hem sevgilinin boyu, hem Nil'in çağrışım yolu ile tasviri yapılıyor.

\footnotetext{
${ }^{7}$ Necati Bey Divanı, Akçă̆ Yay., s.278

${ }^{8}$ Mengi, Prof. Dr. Mine, Eski Türk Edebiyatı Tarihi, Akçağ

Yay., s.112, Ankara 1994

${ }^{9}$ Pala, s.391
} 
3. Benim beglenmesin hadinde zira

Habeş olduğu yok sultanı Mısrın

(Senin haddinle ben beylenmeyeyim, övünmeyeyim zira Mısıra Habeşli birinin sultan olduğu yoktur.)

$\mathrm{Bu}$ beyitte tavir ve sosyal hayata ait Misır ile ilgili veriye rastlamiyoruz.

4. Halas olmaz zenahdanın esiri Müebbed haps imiș zindanı Mısrın

(Senin çene çukurunun esiri olan kurtulamaz. Zira Misır'ın zindanı ebedi hapis imiş.)

Şair burada Misır'a ait bir özellik veriyor. Misır ve zindan deyince doğal olarak akla Yusuf gelecektir. Yusuf uzun süre Mısır zindanlarında yatmıştır. Züleyha'nın iftirası sonucu ${ }^{10}$ Yusuf uzun süre haksız yere Misır zindanlarında kalıyor.

Daha sonra ülkenin geleceği ile ilgili bir rüyayı doğru yorumlayışı neticesinde kurtuluyor. Sevgilinin çene çukurunu görüp aşık olanlar (onun içine düşenler) bir daha kurtulamıyor. Mısır zindanları ve onların içinde yaşam zorluğu bir teşbih unsuru olarak kullanılmış. Zindanların fiziksel tasviri somut olarak anlatılmamış; ama ifade zindanlara ait olumsuzlukları zihinlere çağrışım yolu ile aktarıyor. Bu beyitte ayrıca sevgilinin çene çukuru bir betimleme unsuru olarak verilmiş.

5. Tavaf-1 Kabedir kûyu Necati

Saçı Sâmın ruh-1 handanı Mısrın

(Necati, onun köyü, bulunduğu yer Kabe'nin etrafı gibidir. Saçı Samın saçı ve o Mısır'ın gülen yanağıdır.)

Bu gazelde Mısır değil de Mısır'daki sevgiliye ait özellikleri anlatılmıştır.

\section{KAPLICA}

\section{GAZEL ${ }^{11}$}

Cennete dönmüş durur elkıssa yârân Kaplıca

Ol periler mecma-1 ser çeşme-i cân Kaplıca

Ayağına varır ola bir peri gün başına Var ise bulmuş durur mühr-i Süleyman Kaplıca

Ayine gibi peri-peyker semen-simaları Hoş safalarla çeker bağrına uryân Kaplıca

Aş1k-1 didâr olup gördüğü mahbûba akar Germ olup gül yüzlülerle sürdü devran Kaplıca

Şükr kim sakallıya cennette yer yoktur demez Dopdoludur Bağ-1 Rıdvan gibi gılmân Kaplıca

Kendiyi vakf eyleyip yollar gözetmezdi müdâm Ger Halilullah gibi sevmese mihman Kaplıca

Anadan doğma olur her kim gelirse katına Barekallah ey bu gün her derde derman Kaplıca

Çünkü sen Bursa'da oldun âleme def' ül-melâl Dâim âbâdân olasın şâd u handan Kaplıca

Eski yeni sana hidmed-gâr olamaz gerçi kim

\footnotetext{
${ }^{10}$ Onay, Ahmet Talat, Eski Türk Edebiyatında Mazmunlar, TDV Yay., s.441, Ank. 1992

${ }^{11}$ Necati Bey Divanı, Akçağ Yayınları, s.360-361
}

Pir ile pîr oldun oğlan ile oğlan Kaplıca

Kainat içinde Bursacık gibi bir danesin

Dâm eder gerçi seni erbâb-1 irfan Kaplıca

Vuslat-1 cânân ile şâd et Necati müflisi

Dahi müşküller senin katında âsân Kaplıca

Bilindiği gibi Bursa kaplıcaları ile ünlü bir şehrimizdir. Bursa kaplıcalar açısından çok zengindir. Çekirge'deki Eski Kaplıca'nın temellerinin Bizans devrinden kaldığ söylenmektedir. Hatta Bursa'da hamam kültürü Roma devrine kadar inmektedir. Nitekim Bursa kaplıcalarıyla ilgili en erken bilgi 82 yılında Dion'un konuşmalarında görülür. Paralarda da Bursa hamamları konusunda bilgiler yer alır. Prusa'da basılan bir parada bir binadan su akarken temsil edilmiştir. Yanda ise iki kadın vardır. Bu kadınlar iki sürahiden su dökmektedir. Buradaki figürlerde kaplıcalar anlatılmaktadır ve kadınlar da perilerdir.

Kaplıcalarda 1 lıklık, soğukluk ve sıcaklık bölümleri vardır. Buralardaki hamamların birçoğu çift hamamıdır. Yani erkeklere ve kadınlara ait hamamlar yan yana yapılmıştır. Çekirge'de yapılan hamamların da diğerlerinden farkı yoktur. 1800'lü yıllarda bile bu bölgedeki hamam sayısı 30 civarındadır (Manide Leonay, Mehmet Ziya, Hasan Taib). Çevreyle beraber bunların sayısı 100 civarındadır. ${ }^{12}$

Bursa merkezdeki kaplıcaların en ünlüleri şunlardır.

- Eski Kaplicalar

- Kükürtlü Kaplıcaları

- Çekirge Hamamı

- Çakırağa Hamamı

- Oylat Kaplicaları

- Tümbüldek Kaplıcaları

- Terme Kaplicası

- Sadağ Kaplıcası

Kaplıcalar mekan olarak tatil amaçlı da kullanılır; ama daha çok sihhat bulma gayesiyle ziyaret edilen yerlerdir. İnsanların bir arada bulunduğu kaplıcalar toplum hayatın da önemli yer tutar. $\mathrm{Bu}$ gazelde de Bursa'daki bir kaplica anlatılmaktadır.Kaplıcanın anlatılması, betimlenmesi, tasvir unsurlarıyla verilmesi, gerçek hayatta bir unsurun şiirleştirilmesi gerçekçilik adına önemlidir.

1. Cennete dönmüş durur elkıssa yârân kaplıca ol periler mecma-1 ser çeşme-i cân Kaplıca

(Kaplıca cennete dönmüştür. Çünkü o periler can pınarına toplanmışlar)

Şair burada kaplıcaya toplanan güzelleri görünce orayı cennete benzetiyor. 0 güzeller peri olunca, periye benzeyince mekan da elbette cennete benzeyecektir.

2. Ayağına varır ola bir peri gün başına

Var ise bulmuş durur mühr-i Süleyman Kaplıca

(Sanki kaplıca Süleyma'nın mührünü bulmuştur. Zira her gün bin peri onun ayağına varır.)

Hz. Süleyman yüzüğü sayesinde bütün mahlukata hükm edebiliyordu. Şair burada bütün güzellerin kaplıcaya toplanmalarına bakarak kaplıcanın sanki mühr-i Süleymanı ele geçirdiğini söylüyor. Kaplıca bu mühür sayesinde onlara emr ediyor ve onlar da bu emre uyup kaplicaya geliyorlar.

\footnotetext{
${ }^{12}$ www.bursa.bel.tr/hizmetler/sayfa/742
} 
Burada ima edilen kalabalık gelenlerin niteliği tasvir anlamında hareketli bir görüntüye işaret ediyor.

3. Ayine gibi peri-peyker semen-simaları

Hoş safâlarla çeker bağrına uryân Kaplıca.

(Kaplıca; ayna gibi, ay yüzlü değerli simaları hoş safâlarla üryan bir şekilde bağrına çeker.)

Bu gazelde bu üç beyite kadar bir bölük güzelin kaplıcaya gelişi ve oradaki gelişmeler anlatılıyor. Daha önceki beyitlerde güzeller kaplıcaya gelmiş ve burada toplanmışlardır. Burada ise bu güzeller soyunup kaplıcaya giriyorlar. Aynaya bakan insanı ayna nasıl içine alırsa kaplıca da güzelleri, içine alıyor. Burada insanların kaplıcadaki durumlarının, görüntülerinin tasviri vardır.

4. Aşık-1 didâr olup gördüğü mahbûba akar

Germ olup gül yüzlülerle sürdü devran Kaplıca

(Onların yüzlerinin aşığı olup gördüğü sevgiliye akar. Sıcak olup gül yüzlülerle kaplıca devran sürdü.)

$\mathrm{Bu}$ beyitte artık kaplıca kişileştirilmiştir, Güzeller orada üryan olup sicak kaplicaya girince kaplıca da sanki onlara aşık olmuş gibi yanlarında akar. Burada çizilen manzara, o devir toplum hayatı için oldukça ilgi çekicidir. Kaplıca kültürü ve geleneğinin dönemler arasında ciddi farklar göstermediğini bu tasvirle beraber görmekteyiz. Buradaki betimleme unsurlarına günümüzde de rastlıyoruz.

5. Şükr kim sakalliya cennette yer yoktur demez Dopdoludur Bağ-1 Rıdvan gibi gılmân Kaplıca

(Şükür ki burada cennette yer yoktur diyen, bir sakallı yok. Kaplica cennet gibi gilman doludur.)

Burada kaplicaya yapılan cennet benzetmesi devam ediyor. Kaplıcadaki bayanların güzelliklerini periye benzetmişti. Şimdi de orada bulunan erkekleri gilmana benzeterek cennet tasvirini geliştiriyor. Bilindiği gibi cennetdeki erkeklere gılman denir. Bunu bilen şair burada, bir hoca olmamasına şükrediyor. Zira burada hoca olsa hepsini cennetten atmaktan cehenneme koymaktan bahs edecekti.

Şair, bu vesileyle belki de kendisinin de bu kaplicadan istifade ettiğine sevindiğini söylüyor. $\mathrm{Bu}$ kadar güzelin olduğu yerde olmaktan mutludur.

6. Kendini vakf eyleyip yollar gözetmezdi müdam

Ger Halilullah gibi sevmese mihman Kaplica

(Eğer kaplıca Hz,İbrahim gibi misafir sevmeseydi kendini vakf edip devamlı onların yolunu gözetmezdi.)

Şair bu beyitte Kaplıca'ya ait bir tasviri bilgi veremiyor. Ancak kaplıcaya gelen insanlara karşı kaplıcanın bekleyişi ve o misafirleri isteyişi anlatılıyor. Kaplıca'nın genel görüntüsü ve hareketliliği anlatılıyor. Günümüz kaplıcalarında olduğu gibi o devirde de kaplıcalara özel ilginin olduğu sonucuna varıyoruz. Sağlık ve tatil amaçlı bir mahiyet taşıyan kaplıcalar o dönemde de insanların hizmetine sunulmuştur.

7. Anadan doğma, olur her kim gelirse katına

Barekallah ey bu gün her derde dermân Kaplıca

(Ey bu gün her derde derman olan kaplıca, Allah mübarek etsin, her kim senin katına, gelirse anadan doğma çıplak olur) Şair burada kaplıcaya gelen insanlardan söz ediyor. Buraya, gelenler soyunup suya. giriyor. Bir yerde şairin içten içe kaplıcaya imrendiğini söyleyebiliriz. Dönemin sosyal hayatı açısından kaplıcadaki bu görünüm çok ilginç oluyor. Şair, Allah mübarek etsin (Barekallah) diyerek bu durum takdirkar bir tavırla karşılıyor. Burada betimleme açısında kaplıcadaki kalabalık, gelen insanların soyunup suya girmesi ve orada bir süre o şekilde kalması önemlidir. Gerçek hayatın bir bölümünün tasviri olan bu manzara günümüz açından da benzer görüntülerle kıyas edilebilir.

8. Çünkü sen Bursa'da oldun âleme def'üi-melâl

Dâim âbâdân olasin şad u handan Kaplica

(Ey kaplıca; daima mutlu ve gülen olasın, çünkü sen Bursa'da aleme sikıntı def eden oldun.)

Şair burada kaplıcanın şad edici manzarasına bakıp buraya dua ediyor. Bursa'da halen Çekirge ilçesinde var olan kaplıcaların sıkıntıları dağıtan, insanı kederden uzaklaştıran konumundan son derece memnun olan şair bu yere dua edip alkışlıyor. Kaplıcaların sağlık fonksiyonunun öncüllendiği bu bölümde, bu yerlerin övgüsü ve duası yapılıyor. Biz bu beyitten mutlu insanların, sağlığına kavuşmuş insanların betimlendiğini onların huzurlu hallerini anlıyoruz.

9. Eski yeni sana hidmed-gâr olamaz gerçi kim Pir ile pir oldun oğlan ile oğlan Kaplıca

(Eski yeni herkes sana hizmetçi olamaz gerçi çünkü sen büyük ile büyük, küçük ile küçük oldun.)

$\mathrm{Bu}$ beyitte kaplıcaya gelen insanlardan bahsediliyor. Oraya küçük büyük herkesin gittiğini anlıyoruz. Bu haliyle o çok engin sineli kabul ediliyor. Bu kişileştirme ile ona herkesin hizmetçi olamayacağı belirtilerek övgü yapılıyor. Burada Kaplıca'ya gelen insanların profilini de görmek mümkün. Her yaştan insanın buralardan istifade ettiği anlaşılmakadır. Kaplıcaya gelen insanların fiziksel tasvirinin yanında yaşla ilgili bilgilere de ulaşıyoruz.

10. Kainat içinde Bursacık gibi bir danesin

Dâm eder gerçi seni erbâb-1 irfan Kaplıca

(Sen dünya içinde Bursacık gibi birtanesin, eşin yok ama irfan sahibi olanlar, bilge kişiler seni tuzağa düşürür.)

Burada Bursa, ile beraber kaplıcaya da övgü yapılırken, toplumsal hayata ait bir tasvir unsuru yoktur.

11. Vuslat-1 cânân ile şâd et Necati müflisi

Dahi müşüuller senin katında âsân Kaplıca

(Ifflas etmiş Necati'yi yare kavuşmakla mutlu et. Zira müşküller zor işler senin katında kolaydır.)

$\mathrm{Bu}$ beyitte o dönem toplum hayatına ait bir realiteye değinilmekle beraber kaplıcalara bakış açısına da göndermede bulunulmuştur. Kaplıcaların birçok hastalığa derman olduğu, günümüze de yaygın bir tecrübeyle, kabul edilmektedir. Birçok hastalığa oralarda çözüm bulunduğunu biliyoruz. Başta romatizmal hastalıklar olmak üzere birçok eklem, yara, ağrı... hastalıklarında kaplıcalar derman olarak bilinir.

Bu beyitte de Necâti buradan yola çıkarak derman arıyor. Necati farklı bir derde-ayrılık derdi, yâri görememe derdi-çare arıyor. Kaplıcalardaki insanların bir arada olma durumundan yararlanarak sevgiliyi orada görme ihtimaliyle kaplıcadan bu vuslata araç olmasını istiyor. Bu şiirde hayatın oldukça canlı, renkli bir şekilde ele alındığını görüyoruz. Özellikle yapılan tasvirlerde bu canlılığın şahidi oluyoruz. Hayatın kendisi en gerçekçi haliyle betimleniyor.

\section{B) NECATI'NIN REDIFI ŞAHIS ISMI OLAN GAZELLERINNDEKI TASVIIR UNSURLARI}

\section{I) MEMI}

\section{GAZEL $^{13}$}

Yaktı aşkın beni gam oduna nâgah Memi Yanalım yakılalım çare nedir ah Memi

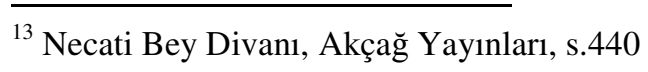


Çün unuttun bana ahd ile yümin eylediğin

Komaya, sende benim hakkımı Allah Memi

Beni sevdaya salıb eyledi divane saçın

Nideyim, neyleyeyim ah Memi veh Memi

Ger ölürsem yazılır seng-i mezarımda benim

Beni hâk eyledi aşkın nideyim ah Memi

Nideyim neyleyeyim çare nedir can vereyim

Çün Necati gamı yaktı oda nagah Memi

Öncelikle Mehmet isminin kısaltılmışı olan Memi hakkında kaynaklarda bir bilgiye rastlayamadık. Bu gazelde kişiye ait tasviri özelliklerden ziyade şairin sitemli aşk söyleyişleri ön plandadır. Her şeyden önce Meminin bir erkek kişi olduğu söylenirse divan şiirinin tartışmalı konusu olan sevgilinin cinsiyeti meselesi ile karşı karşıya kalırız. Bu yönünü bırakıp biz yakalayabildiğimiz tasvir unsurlarına değineceğiz.

1. Yaktı aşkın beni gam oduna nâgah Memi Yanalım yakılalım çare nedir ah Memi

İlk beyitde şair, Memi'ye suçunu bildirir şekilde sesleniyor, Memi'nin yakıcılık özelliği var. Memi şairi vakitsiz bir şekilde aşk oduna yakmıştır. Şair bundan şikayetçi olmakla birlikte bunu kabulleniyor. "Yanalım yakılalım" diyor ama "çare nedir?" demeden de edemiyor. Kısaca bu beyitte Memi şairi aşk ateşiyle yakan bir özellikte sunulmuştur. Burada aşk ateşine düşen insana ait psikolojik bir tasvirin ipuçlarını yakalıyoruz. O psikolojinin birtakım fiziksel betimlemeleri tahmin ettirebileceğini biliyoruz.

2. Çün unuttun bana ahd ile yümin eylediğin

Komaya, sende benim hakkımı Allah Memi

Birinci beyitde vefasız sevgili tipiyle karşımıza çıkan Memi ikinci beyitte bu özelliği kuvvetlendirilerek sunuluyor. Çünkü Memi verdiği sözü tutmamış yeminine sadık kalmamıştır. Şair onun bu duyarsızlığına karşı bir şey yapamayıp onu Allah'a havale ediyor.

3. Beni sevdaya salıb eyledi divane saçın

Nideyim, neyleyeyim ah Memi veh Memi

Üçüncü beyitte bu vefasız sevgilinin saçına ait bir özellik veriliyor. Divan edebiyatında en çok kullanılan güzellik unsuru saç sayılabilir. Mû, gîsû, zülf gibi adlar altında ve birçok yönden ele alınan saç, sayısız teşbih ve mecazlara konu olmuştur. Şekli kokusu, rengi vs. yönlerden birçok beyte anlam verir. Öncelikle perişan, düzensiz, dağınık, uzun vs. durumlarıyla aşığın aklını başından alır onu esir ve perişan eder. Siyah ve dağınıktır ${ }^{14}$. Meminin saçı klasik divan şiiri anlayışında çok sık karşılaşılan bir özellik gösterip aşı̆̆ı divane ediyor. Sevgilinin saçının perişanlığı aşığı perişan ediyor, Bu hal karşısında ne edeceğini bilemeyen şair elini dizine vurup ah u vah ediyor. Burada sevgilinin klasik saç tasviri, saçın rengi, dağınıklığı ile bu görüntünün aşı ̆̆ı da kendine benzettiği durum tasvir ediliyor.

4. Ger ölürsem yazılır seng-i mezarımda benim

Beni hâk eyledi aşkın nideyim ah Memi

Dördüncü beyitde, şair çaresizliğin son noktasını yaşıyor. Daha önceki beyitlerde görüldüğü gibi insafsız sevgili Memi aşı ̆̆ı divane etmiştir. Aşığın yapacak bir şeyi kalmamıştır. Bunun neticesi olarak şair, "ölürsem mezar taşma beni Memi'nin aşkı toprak eyledi" diye yazılmasını istiyor. Mezar taşına ölenle ilgili yazı yazmak eskiden beri var olan bir

\footnotetext{
${ }^{14}$ Pala, s.48
}

gelenektir. Sosyal hayatın bir parçası olan bu gelenek birçok açıdan önemlidir. Öleni bilmek, dönemin kültürünü anlamak, gibi çeşitli alanlarla ilgili bilgi verir. Dönemin tasviri açısından bilgi kaynağı da olan bu gelenek günümüzde de varlığını sürdürmektedir. Burada mezar taşı, mezarlık, betimlenen unsurlar olarak karşımıza çıkıyor.

5. Nideyim neyleyeyim çare nedir can vereyim Çün Necati gamı yaktı oda nagah Memi

Son beyitte şair çaresizliğini dile getirip, ilk beyitte aşığı aşk oduna yakma özelliği verilen Meminin bu özelliğini tekrar ediyor. Şair can vermekten başka çare bulamıyor.

Bu gazelde redif olan kişi adı (Memi) kendine has özellikler göstermiyor. Klasik divan güzeline ait özelliklerle veriliyor.

\section{MESTI ÇELEBİ}

\section{GAZEL $^{15}$}

Dehenin andığıma yok yere Mesti Çelebi El urur gamzelerin hançere Mesti Çelebi

Gözüne hey demez isen diyeler öldürtmüş Bir müselmanı iki kefere Mesti Çelebi

Yalnız ben deyilem her kişi divane durur Sen peri çehre melek manzara Mesti Çelebi

Kad ü ruhsarını benzetmeğe adem utanır Serv-i naz ile gül-i ahmere Mesti Çelebi

Bana. bir buse satarsan vereyim helvalık Canım ol lâli şekerpervere Mesti Çelebi

Ağzının ölçüsünü aldım yoğ imiş zerre kadar
Mihr kapındaki aşıklara Mesti Çelebi

Ey Necati kabağın kanlı yaş ile doldur Ola kim mey kıla sagara Mesti Çelebi

Necati'nin bu gazelinde göze ilk çarpan özellik yine kadına, ait olması gereken sevgili özelliklerinin erkeğe verilmesidir. $\mathrm{Bu}$ gazeldeki tasvirler sevgilinin leyyit motif diyebileceğimiz klasik fiziki görüntüsüdür. Burada var olandan ziyade idealize edilen mazmunlara rastliyoruz.

Şair bir önceki gazelde Memi için kullandığı klasik divan sevgilisi özelliklerini bu gazelde değişik şekillerde yine kullaniyor.

1. Dehenin andığıma yok yere mesti Çelebi

El vurur gamzelerin hançere Mesti Çelebi

$\mathrm{Bu}$ beyitde. şair sevgilinin ağzı ve gamzesine ait klasik özellikleri veriyor. Şair sevgilinin ağzını anınca dudakların yanındaki kılıca benzeyen gamzeler birer hançer hükmüne geçiyor. Mesti Çelebi'nin bu beyitte kılıca benzeyen gamzelerini betimlenmiş bir özellik olarak görüyoruz. Gamze tasvirinin Divan şiirinde sıklıkla kullanılmasına burada da şahit oluyoruz.

2. Gözüne hey demez isen diyeler öldürtmüş Bir müselmanı iki kefere Mesti Çelebi

Bu beyitte Mesti Çelebi'nin yüz özelliklerine devam edilmiş. Bu beyitte şair sevgilinin gözünün fonksiyonlarına değiniyor. Şair onun gözlerini iki kafire benzetiyor. Bu iki kafir göz eğer kontrol edilmezse aşığı öldürecektir. İnsanlar da "iki kafir bir

\footnotetext{
${ }^{15}$ Necati Divanı, Akçă̆ Yay. s.440
} 
müslümanı öldürmüş" diyecektir. Sevgilinin gözlerindeki acımasızlık ve etki vurgulanıyor. Gözün bakış şekli betimleniyor. Gözdeki o öldürücü kuvvetin yüze nasıl yansıdı̆̆ını tasvir edilmiş gibi hayalimizde canlandırıyoruz.

3. Yalnız ben değilem her kişi divane durur Sen peri-çehre melek manzara Mesti Çelebi

Bu beyitde sevgilinin yüz özelliklerinin tasviri devam ediyor. Onun yüzü periye benzetiliyor. Bu yüzden herkes ona aşktır.

4. Kad u ruhsarını benzetmeğe adem utanır

Serv-i naz ile gül-i ahmere Mesti Çelebi

$\mathrm{Bu}$ beyitde yüz tasvirinin yanı sıra boy tasviri ve benzetmesi de işin içerisine giriyor. Sevgilinin yüzünün güzelliğinin hakkı kırmızı güle benzetmekle de verilemezken aynı düşünce boyu için de geçerlidir. Sevgilinin boyunun uzunluğu düzgünlüğü, salınışı serv-i nazı yarıda bırakır. İnsanlar bu benzetmeleri yapmaya cesaret edemezler. Zira işin hakkını vermiş olmazlar. Sevgilinin endam tasvirinin yapıldığı bu beyitte mübalağaya başvurulmuş.

5. Bana bir buse satarsan vereyim helvalık Canım ol lâli şekerpervere Mesti Çelebi

Şair bu beyitde yüz tasvirine devam ediyor. Bu sefer konu dudaklardır. Sevgilinin dudakları şeker seven özelliği ile verilmiş. Şairin buradaki niyeti sevgiliyi öpmektir. Eski kültürde helvalık vermek diye bir gelenek vardır. Bu geleneğe göre elbise, ayakkabı gibi bir şey yaptırıldığı zaman çıraklara bir bahşiş verilirdi. Bu bahşie şerbetlik veya helvalık denir. ${ }^{16}$ Dönem kültürüne ait bu özellik sevgili için kullanılmış. Burada sosyal hayata ait bir tasvir yapılmış.

6. Ağzının ölçüsünü aldım yoğ imiş zerre kadar

Mihr kapındaki aşıklara Mesti Çelebi

$\mathrm{Bu}$ beyitte şair sevgilinin düşünce yapısını veriyor. Sevgilinin ağzını arayan aşık onun kapısındaki aşıklara zerre kadar sevgisinin olmadığını anladığını söylüyor. Ayrıca olayın bir diğer yönü daha var. Divan şiirinde sevgilinin ağzı küçüktür. Hatta ağız yok denecek kadar belirsizdir. Fuzuli bir gazelinde:

"Ağzın için yok dediler, dediklerince var imiş" derken bu anlayışı örneklendirir. Biz bu beyitte tasvir unsuru olarak ağzın küçülüğünü görüyoruz.

7. Ey Necati kabağın kanlı yaş ile doldur

Ola kim mey kıla sapana Mesti Çelebi

Son beyitde şair çaresizliğimi vurguluyor. Şair su tasını ağlayarak kanlı yaş ile dolduruyor. Zira sevgilinin bîr gün mey içesi gelirse şarap diye o kasedeki kanlı yaşın kırmızı rengine aldanıp içmek için o kaseyi eline alabilir. Böylece aşı ğın durumundan haberdar olabilir,

Sevgilinin hayali fiziksel nitelikleri bu gazelin birçok beyitinde görülmekle beraber, onun ruhsal betimlemesine de yer verilmiş. Daha ziyade acımasız, insafsız bir ruhla karşımıza çıkan sevgili iki yönlü bir tasvire tabi tutulmuş.

\section{III. ŞEYHî}

\section{GAZEL $^{17}$}

Göz yaşı sanma benim seyl-i revanim Şeyhi Lebini yad edecek kaynadı kanım Şehyi

Ölürüm mihr-i cemaline hevadar olurum

\footnotetext{
${ }^{16}$ Onay, Ahmet Talat, Divan Şiiri Sözlüğü, Birleşik Yay., s.190, Ankara 2007

${ }^{17}$ Necâti Divanı, Akçağ Yay. s.432
}

Şuna dek kim kala bir zerre nişanım Şehyi

Ben kocaldım gamı aşkınla, yiğitlik bu mudur Hele ey pir olası taze cevanım Şehyi

Nem ola dersin olayın öleyim dirileyim Edeyim sana feda can u cihanım Şehyi

Ölüm sensiz olacak sınasım kendözümü Gel firak eyleme kıtma bana canım Şehyi

Der isem, nam-1 Necati'ye Nizami'ye mürid Umarım bulmaya sözümde yalanım Şehyi

Necati'nin bu gazelindeki tasvir unsurlarına geçmeden evvel, Şeyhi'nin hayatıyla ile ilgili bir takım bilgilerin aktarılmasında fayda vardır. 15 yy. Anadolu sahası Türk edebiyatının en önemli şahsiyetlerinden olan Şeyhi bu yüzyılın ilk yarısında yaşamıştır. Doğum yeri Germiyandır. Öğrenimini memleketinde tamamladıktan sonra bilgisini ilerletmek için İran'a gitmiş orada tıp, tasavvuf, edebiyat alanlarında bilgisini geliştirmiş ve daha çok göz hekimliğinde derinleşmiştir.

Tıpla ilgisinden dolayı kendisine hekim Sinan denmiştir. İran dönüşü Ankara'da Hacı Bayram Veli'ye intisab etmiş ve Şeyhi mahlasını da bu yüzden almıştır. Memleketinde hekimlik yapan Şeyhi, öncelikle Germiyan Beyi 2. Yakub'un emrine, daha sonra Osmanlı padişahı Çelebi Mehmet ile 2. Murat'a intisab etmiştir. Karaman savaşı sırasında Çelebi Mehmed'in ağrıyan gözünü tedavi etmiştir. Buna karşılık kendisine hediye ve bir köy tımar verilmiştir. Ayrıca hükümdarın özel doktoru olmuştur. Tezkireler 15. yy'da Şeyhi'nin mesnevide Ahmet Paşa'nın kaside de Necati'nin ise gazelde en usta şair olduğunu yazarlar. Görüldüğü üzere Necati ile Şeyhi aynı devrin insanlarıdır.

Bu gazele genel olarak baktığımızda Necati'nin Şeyhi'ye karşı olan büyük bir muhabbeti, görülür.

1. Gözyaşı sanma benim seyl-i revanım Şeyhi Lebini yad edecek kaynadı kanım Şeyhi

$\mathrm{Bu}$ beyitte şeyhe ait herhangi bir tasvir yapılmıyor. Sadece bir seslenme ile Necati'nin şeyhe muhabbetini izhar edişi görülüyor. Burada Şeyhi'nin dudaklarını anınca Necatinin kanının kaynaması Şeyhi'nin şiirleri için söylenmiş. Onun şiirleri Necati'yi heyecanlandırıyor, Yani Necati Şeyhi'nin şiirlerinin etkisini tasdik ediyor. Dudaklar burada betimleme unsuru değil kelama, şiire ait bir mürsel mecazdır.

2. Ömrüm mihr-i cemâline hevadar olurum

Şuna dek kim kala bir zerre nişanım Şeyhî

Bu beyitte "mihr-i cemal" deyip Şeyhi'nin yüzünün güneşe benzetilmesi bir tasvir unsuru olarak karşımıza çıkıyor. Ayrıca şairin "bir zerre nişanım" diyerek çizmeye çalıştığı bedensel zayıflığı, küçülmeyi yok olmaya doğru gidişi anlatması gözümüzde bir şekil oluşturarak betimlemeye yer verilmiş oluyor.

3. Ben kocaldım gam-1 aşkınla, yiğitlik bu mudur

Hele ey pîr olası taze cevanım Şeyhî

Üçüncü beyitte şair yaş itibariyle Şeyhi ile kendini karşılaştırıyor. Kendisinin yaşlılığını "Ben kocaldım" diyerek belirtirken "taze cevanım" diyerek Şeyhi’nin gençliğini vurguluyor. Gizliden gizliye onun gençliğini kıskanıyor. Bu beyitte samimiyet ve dostluktan gelen şakalaşma mahiyetinde bir söyleyiş var. Şeyhi'nin gençliği ona ait bir tasvir sayılır.

4. Nem ola dersin olayın öleyim dirileyim 
Edeyim sana feda can u cihanım Şeyhî

5. Ölüm sensiz olacak sınasım kendözümü

Gel firak eyleme kıyma bana canım Şeyhî

Birbirinin ardından gelip birbirini tamamlayan bu beyitlerde Necati, Şeyhî’ye olan sevgisini, iştiyakını, onun uğrunda canından geçebileceğini anlatıyor. $\mathrm{Bu}$ kavi muhabbetin candan geçme kertesine kadar, söylem olarak, gelmesi Divan şiirinin kendi dünyasında karşımıza çıkar.

4 ve 5 . beyitlerde şair Şeyhi'ye olan muhabbetinin derecesini belirtirken canını ortaya koyuyor. Son beyitte Necati kendini büyütürken Şeyhi'den tasdik istiyor. Kendi şiirini Nizami'nin şiirine mürid gösterirken Şeyhi'nin onun bu cüretini tasdik etmesini istiyor.

6. Der isem nazm-1 Necati'ye Nizamî'ye murid

Umarım bulmaya sözümde yalanım Şeyhî

Bu sonuncu beyitte Necati, kendini ünlü şair Nizamî’ye, onun şiirine mürid gösteriyor. Burada Necatî kendi şiirini bir yönüyle büyütüyor. Biliyoruz ki Nizamî Divan şairlerinin bir kısmını ciddi anlamda etkilemiş, eserlerine nazireler yazılmış önemli bir şairdir. Necati burada Şeyhî’ye de çok önem verdiğini onun tasdikini isteyerek gösteriyor.

Özet olarak söyleyecek olursak; kimi beyitlerde rastlamasak bile bazı beyitlerde betimlemeler öne çıkıyor. Gerçek hayattan kişilerin varlığı ve bazı yönleriyle tasvirleri ve buna dönem edebiyatının klasikleşmiş ve kalıplaşmış betimleme ve kullanımları da eklenince gözümüzün önünde bir tablo canlaniyor.

$\mathrm{Bu}$ gazelde Necati, genelde tasvirlerde klasik kalıpları kullanmış. Ancak gerçek hayattan bir kişi olarak Şeyhi'nin anlatılması hayatın daha realist olarak şiire girmesini sağlamış.

\section{SONUÇ}

Necâti'nin redifi yer ve insan ismi olan gazellerindeki tasvir unsurlarını belirttikten sonra, bu unsurları iki temel noktada toplayabildiğimizi söyleyebiliriz. Bu noktaların ilki şudur: Klasik edebiyat içinde mazmunlaşmış, kalıplaşmış unsurların betimlemesi bilinen özelliklerle yapılmıştır. Bu noktaların ikincisi ve önemli olanı ise şairin kendi gözlemleri sonucu yaptığı öznel tasvirlerdir.

Necâti, Kâbe'yi anlatırken gerçi herkesin bildiği ve haberdar olduğu özelliklerini kullanıyor ve betimleme unsuru olarak önümüze koyuyor ama yorum kendine aittir. Keza diğer gazellerde de aynı durumla karşılaşıyoruz. Özellikle "Kaplıca" redifli gazelde şairin mekân tasviri yanında o günkü toplum hayatından bir kesit sunması ve o günkü hayata ait verileri aktarması, şiiri gerçek hayatın içinde aktif hâle getiriyor.

"Şeyhî" redifli gazelde de tasvirler ve şahıs anlatımı Divan şiiri kasidelerindeki genelleşmiş tasvir ve övgülerden uzaktır. Belirtilen özellikler sadece Necâti'nin Şeyhî'ye bakışını verir. Bunun yanında bazı gazellerde de tasvir unsurları çok fazla yer tutmuyor.

Son söz olarak şunu söylemek gerekir: Divan şiirinde tasvir çeşitli şekillerde karşımıza çıkıyor. Bu tasvirler şiiri gerçek hayata yaklaştırıyor. Hayat, şiirlere temas ediyor. Yer yer o devirdeki şahıs ve mekanlar döneme ait özellikleri ile anlatılıyor. Bu özellikler Divan şiirine hem çeşni katıyor hem de onunla hayat arasinda temas kuruyor.

\section{KAYNAKLAR}

Solmaz, Yrd. Doç. Dr. Süleyman, Necati Bey, Akçağ, Ankara, 2012

Şentürk, Ahmet Atilla-Kartal Ahmet, Eski Türk Edb. Tarihi, Degâh, İst. 2011

Tarlan, Ali Nihat, Necati Bey Divanı, Akçağ, Ankara 1992

Pala, İskender, Ansiklopedik Divan Şiiri Sözlüğü, Akçağ, Ankara,

İslam Ansiklopedisi, Divan Edb. Mad. Meb, 6-Cilt, 5-6

Mengi, Prof. Dr. Mine, Eski Türk Edebiyatı Tarihi, Akçağ, Ankara, 1994

Onay, Ahmet Talat, Eski Türk Edebiyatında Monmunlar, TDV, Ankara, 1992

www.bursa.bel.tr/hizmetler/sayfa/742

Onay, Ahmet Talat, Divan Şiiri Sözlüğü, Birleşik Yay, Ankara, 2007 